\title{
potret keluarga matrilineal minangkabau dalam dua NOUEL PENGARANG ETNIS MINANGKABAU
}

\section{THE PORTRAIT OF MATRILINEAL FAMILY OF MINANGKABAU IN TWO NOVELS WRITTEN BY MINANGKABAU ETHNIC WRITERS}

\author{
Renti Mahkota, Aquarini Priyatna, Sri Rijati Wardiani \\ Program Studi Magister Ilmu Sastra, Fakultas Ilmu Budaya, Universitas Padjadjaran \\ Jalan Ir. Soekarno Km. 21, Jatinangor-Sumedang 45363, Indonesia \\ e-mail: rentimahkota3@gmail.com, aquarini@unpad.ac.id, sri.rijati@unpad.ac.id
}

DOI: 10.30959/patanjala.v11i2.504

\begin{abstract}
Abstrak
Penelitian ini bertujuan untuk menunjukkan perbandingan dan persamaan potret keluarga matrilineal Minangkabau yang ditampilkan dalam dua novel pengarang etnis Minangkabau, yaitu novel Negeri Perempuan karya Wisran Hadi dan novel Aku Tidak Membeli Cintamu karya Desni Intan Suri. Untuk menunjukkan potret keluarga matrilineal Minangkabau dalam dua novel pengarang etnis Minangkabau peneliti menggunakan teori sastra bandingan sebagai landasan dalam penelitian ini. Metode dalam penelitian secara khusus menggunakan metode perbandigan sastra. Hasil penelitian menunjukkan bahwa ditemukan dua bentuk potret keluarga matrilineal di Minangakabau yang ditampilkan dalam kedua novel pengarang etnis Minangkabau. Pertama keluarga yang menganut sistem matriarkal-matrilneal, yaitu pihak perempuan (ibu) yang memegang kekuasaan utama di dalam keluarga. Kedua, keluarga yang menganut sistem patriarkal-matrilineal, yaitu kekuasaan utama dipegang oleh kaum laki-laki. Kekuasaan pada potret keluarga bentuk kedua ini bukan berada di pihak ayah (suami), melainkan berada di pihak mamak (saudara laki-laki ibu).
\end{abstract}

Kata kunci: keluarga, matrilineal, Minangkabau, novel, sastra bandingan

\section{Abstract}

This study aims at showing the comparison and similarities of Minangkabau matrilineal family presented in two ethnic novels entitled Negeri Perempuan by Wisran Hadi and Aku Tidak Membeli Cintamu by Desni Intan Suri. To discuss the portrait of Minangkabau matrilineal family in these two novels, the researcher used comparative literature theory to frame the study. The present study specifically used the comparative literature method as its research method. Based on the research findings, it was found that there are two types of matrilineal family in Minangkabau presented in both novels. The first type is the family which follows the matriarchal-matrilineal system. This type believes that the women (mother) side takes the main power in their family. The second type is the family which follows the patriarchal-matrilineal system. This system believes that the main power is on the men's side. The main power in the second system is not actually on the father's side (husband); however the main power is on the uncle's side (the mother's brother).

Keywords: family, matrilineal, Minangkabau, novel, comparative literature.

\section{A. PENDAHULUAN}

Kehidupan

Minangkabau masyarakat menganut sistem kekerabatan matrilineal dan sistem sosial patriarki, bukan matriarki. Ranji (silsilah keluarga) ditarik menurut garis ibu, tetapi kekuasaan didominasi bukan oleh perempuan atau ibu, melainkan laki-laki. Sebagaimana yang dipaparkan oleh 
Syahrizal dan Sri Meiyenti (2012) dalam sistem matrilineal Minangkabau walaupun garis keturunan berdasarkan perempuan namun yang berkuasa adalah laki-laki. Laki-laki bertindak sebagai pemimpin dalam kaumnya. Laki-laki juga diposisikan sebagai wakil dari kaumnya dalam masyarakat nagari atau masyarakat yang lebih luas. Subadio dan T.O Ihromi (1978: 29) menyebutkan bahwa akibat dari sistem matrilineal kaum perempuan di Minangkabau menduduki tempat yang khas. Lebih lanjut, ia menjelaskan bahwa kedudukan perempuan masih selalu lebih rendah daripada kedudukan kaum lelaki, meskipun anak-anak termasuk keluarga si ibu. Dapat dikatakan, dalam budaya Minangkabau kaum lelaki itu merupakan pihak yang berkuasa dan dominan, sehingga mereka dapat menentukan hidup dan nasib perempuan (Subadio dan T.O Ihromi, 1978: 29).

Berbeda dari sistem patriarki secara umum, yaitu kekuasaan di dalam keluarga berada pada pihak ayah sebagai kepala keluarga yang mengontrol, menguasai, sekaligus mewarisi harta pusaka secara patrilineal. Di Minangkabau sistem kekuasaan (patriarki-matrilineal) diperankan oleh mamak dalam lembaga keluarga luas (kerabat), bukan oleh bapak (suami) dalam keluarga inti (nuclear family). Mengenai harta pusaka, kekuasaannya hanya sebatas sebagai pengontrol, tetapi tidak memiliki atau mewarisi, sebagaimana yang di argumentasikan oleh Azwar (2001: 74). Azwar (2001: 42) menyebutkan bahwa secara silsilah yang berdasarkan pada pola matrilineal, terkait dengan fungsi dan peran laki-laki di tengah kerabat, masyarakat Minangkabau tersusun atas: tingkatan penghulu, mamak dan kemenakan. Sebagaimana yang dipaparkan dalam ungkapan Minangkabau, yaitu kamanakan barajo ka mamak, mamak barajo ka panghulu, panghulu barajo ka nan bana, dan nan bana badiri sandiri (kemenakan berada dibawah pimpinan mamak, mamak dipimpin oleh penghulu, dan penghulu dituntun oleh kebenaran nilai dan norma adat serta agama).

Menurut Benda-Beckmann (2000: 96) kemamakan bukanlah satu-satunya individualisasi kedudukan sosial tempat kekuasaan berada. Kekuasaan mamak meliputi perwakilan kelompok seutuhnya, tetapi dalam masalah-masalah di dalam (intern) kelompok, kekuasaan diberikan pada kedudukan perempuan tertua dalam kelompok. Perempuan tertualah yang memegang kekuasaan tertinggi di rumah dan ia juga memiliki suara yang dominan dalam masalah harato (harta). Subadio dan T.O Ihromi (1978) menyebutkan bahwa kekuasaan perempuan tidak sama dengan laki-laki di Minangkabau, kekuasaan perempuan lebih tinggi di dalam lingkungan keluarga besarnya. Hal ini sebagaimana yang dijelaskan oleh Subadio dan T.O Ihromi (1978:19-20) bahwa "di atas mamak di dalam lingkungan keluarga Minangkabau, sebenarnya masih ada ibunda suku bersama, jika ia masih hidup. Bagaimanapun juga, jika harus dikeluarkan suara-suara di dalam urusan-urusan kekeluargaan, maka ibunda suku itu tetap merupakan kekuasaan tertinggi dalam sebuah paruik dalam jurai." Ibunda suku bersama di dalam keluarga Minangkabau adalah penentu kebijakan atas segala persoalan-persoalan terkait kekeluargaan. Yang dimaksud ibunda suku bersama menurut Willinck mengacu kepada Mandeh Sako atau Bundo Kanduang. Secara umum Bundo Kanduang merupakan panggilan untuk kaum perempuan yang merujuk pada perempuan yang sudah berkeluarga (menikah). Bundo Kanduang adalah figur sentral dalam keluarga rumah gadang.

Bentuk-bentuk yang telah di paparkan sebelumnya inilah yang sering dimunculkan baik dalam latar (alur, tempat, waktu) cerita maupun konflikkonflik yang diangkat oleh penulis-penulis etnis Minangkabau dalam karya-karya sastranya. Di antaranya terdapat pada karya sastra berupa novel yang berjudul Negeri Perempuan dan novel Aku Tidak 
Membeli Cintamu. Novel Negeri Perempuan merupakan novel yang ditulis oleh Wisran Hadi. Novel ini adalah novel kedua yang diterbitkan Hadi pada tahun 2001 oleh Pustaka Firdaus. Selanjutnya novel Aku Tidak Membeli Cintamu yang ditulis oleh salah satu penulis perempuan Minangkabau yang bernama Desni Intan Suri. Novel ini pertama kali terbit pada tahun 2012 oleh Penerbit Jendela (Lini Zikrul Hakim).

Setelah saya melakukan pembacaan terhadap kedua novel, saya menemukan bahwa latar sosial kultural Minangkabau di dalam kedua novel berbeda. Jika novel Negeri Perempuan karya Wisran Hadi menampilkan latar sosial kultural masyarakat Minangkabau di daerah Batu Sangkar (Pagaruyung) yang merupakan wilayah yang termasuk ke dalam Luhak Tanah Datar (daerah asal atau darek), sedangkan novel Aku Tidak Membeli Cintamu karya Desni Intan Suri menampilkan latar sosial kultural masyarakat Minangkabau di Pariaman yang termasuk ke dalam Luhak Agam (daerah baru atau pesisir).

Kedua wilayah yang menjadi latar sosial kultural masyarakatnya sama-sama berada di Luhak yang kekuasaannya berada di tangan penghulu. Hal ini secara dasar disebutkan dalam pepatah adat Minangkabau, yaitu luhak nan bapanghulu, rantau nan baraja. Artinya di negeri-negeri di lingkungan luhak yang tiga (Luhak Agam, Luhak Tanah Datar, dan Luhak Limo Puluah Koto) kekuasaan berada di tangan penghulu dengan pengkat andiko dengan panggilan datuak dan di daerah rantau yang berkuasa adalah raja.

Dalam luhak nan tiga (mengacu kepada makna geografis administratif) terdapat dua laras atau lareh (bermakna hukum, yaitu tata cara adat turuntemurun), yaitu laras Koto Piliang dan laras Bodi Caniago. Perbedaan pokok antara kedua laras ini terletak pada tata susunan nagari dan pangkat kepenghuluan. Pada novel Negeri Perempuan saya menemukan sistem kelarasan masyarakat Minangkabau yang menganut sistem kelarasan Koto Piliang. Sistem laras Koto Piliang adalah paham yang berasal dari Dt. Ketumanggungan yang bersifat otokrasi. Sedangkan di dalam novel Aku Tidak Membeli Cintamu tidak diceritakan atau dibahas mengenai tata susunan nagari dan pangkat kepenghuluan (perihal kelarasan), sehingga saya tidak dapat menentukan sistem kelarasan apa yang ditampilkan. Akan tetapi, novel Aku Tidak Membeli Cintamu lebih menceritakan sosial kultural masyarakat Minangkabau di Pariaman mengenai tradisi uang jamputan.

Novel Negeri Perempuan karya Wisran Hadi telah cukup banyak diteliti. Penelitian terhadap novel Negeri Perempuan saya temukan sebanyak lima penelitian, diantaranya penelitian Yelmi Andriani (2011) yang membahas bentukbentuk perubahan sosial masyarakat Minangkabau yang ditampilkan dalam novel. Setelah itu, penelitian Yasnur Asri (2013) membahas bentuk refleksi ideologi perempuan Minangkabau yang ditampilkan dalam novel Negeri Perempuan karya Wisran Hadi, yaitu ideologi sosial dan politik. Kemudian, Kurnia Ningsih (2004) melakukan penelitian yang membahas bagaimana posisi perempuan di Minangkabau pada era modrernisasi. Selanjutnya, penelitian Hidayati Sani (2017) membahas bentukbentuk citra perempuan Minangkabau yang ditampilkan di dalam novel. Berikutnya, Indah Pelita (2017) membahas citra perempuan Minangkabau yang ditampilkan dalam dua novel, yaitu novel Negeri Perempuan dan novel Limpapeh dengan menggunakan teori sastra bandingan.

Sedangkan penelitian yang telah dilakukan oleh peneliti sebelumnya terhadap novel Aku Tidak Membeli Cintamu karya Desni Intan Suri saya temukan sebanyak enam penelitian, diantaranya penelitian Nelvia Syafnita (2014) membahas bagaimana citra perempuan di Minangkabau ditampilkan dalam novel. Berikutnya, penelitian Rumiana (2015) membahas bentuk sistem nilai budaya Minangkabau yang 
ditampilkan dalam novel. Selanjutnya, Novianti Hasmi (2015) membahas bagaimana bentuk problematika kebudayaan yang ditampilkan dalam novel. Setelah itu, Fauzi Friade (2016) membahas persoalan-persoalan terkait tradisi perkawinan yang ditampilkan dalam novel. Kemudian, penelitian Desi Susanti membahas problematika kebudayaan Minangkabau serta bentuk interaksi sosial yang terdapat dalam novel. Terakhir penelitian yang dilakukan Nidianti Lidya (2018) yang membahas bentuk dan dampak persepsi yang keliru terhadap adat kawin bajapuik yang ditampilkan dalam novel.

Berangkat dari penelusuran
penelitian yang telah dilakukan sebelumnya, dapat diketahui bahwa belum ditemukan penelitian mengenai bagaimana potret keluarga Matrilineal di Minangkabau yang ditampilkan di dalam dua novel pengarang etnis Minangkabau, yaitu novel Negeri Perempuan karya Wisran Hadi dan novel Aku Tidak Membeli Cintamu karya Desni Intan Suri. Oleh sebab itu, tulisan ini diharapkan dapat turut berkontribusi dalam diskusi mengenai potret keluarga matrilineal di Minangkabau.

\section{B. METODE PENELITIAN}

Pada penelitian ini, saya akan menggunakan teori sastra bandingan untuk membandingkan bagaimana potret keluarga matrilineal Minangkabau yang ditampilkan di dalam kedua novel yang dijadikan sebaga objek dalam penelitian ini. Istilah sastra bandingan pertama kali muncul di Prancis pada tahun 1816. Dalam perkembangan, terdapat dua mazhab sastra bandingan yang terkenal, yaitu mazhab Eropa dan Amerika. Mazhab Eropa menekankan pada penelitian antarkarya sastra saja, sedangkan mazhab Amerika berpendapat bahwa di dalam sastra banding diperbolehkan memperbandingkan sastra dengan disiplin bidang lain, seperti seni, filsafat, dan bidang-bidang lain (Damono, 2005:10). Namun demikian, kedua mazhab tersebut bersepakat bahwa sastra bandingan harus bersifat lintas negara, artinya berusaha membandingkan sastra satu negara dengan sastra negara lain.

Seiring perkembangan ilmu pengetahuan, muncul kritikan terhadap pandangan yang dianut oleh kedua mazhab. Menurut Damono (2005: 7) sastra bandingan bukan sekedar mempertentangkan dua sastra dari dua negara atau bangsa yang mempunyai bahasa yang berbeda, tetapi sastra bandingan lebih merupakan suatu metode untuk memperluas pendekatan atas sastra suatu bangsa saja. Tidak hanya menunjukkan bahwa perbandingan pada sastra antarbangsa, tetapi batasan sastra bandingan dapat menunjukkan perbandingan sastra sesama bangsa sendiri, misalnya antarpengarang, antargenetik, antarzaman, antarbentuk, dan antartema. Pada penelitian kali ini saya akan membandingkan sastra antarpengarang novel Minangkabau dalam menampilkan potret keluarga matrilineal Minangkabau.

Secara umum, dalam penelitian ini saya menggunakan metode kualitatif. Dengan demikian, penelitian ini menghasilkan data deskriptif berupa kata-kata tertulis atau lisan dari objek yang diamati (Moleong, 2004). Penelitian dengan menggunakan metode ini bertujuan untuk memaparkan keadaan objek penelitian berdasarkan data yang muncul. Objek penelitian ini adalah karya sastra yang berupa novel berjudul Negeri Perempuan karya Wisran Hadi dan novel Aku Tidak Membeli Cintamu karya Desni Intan Suri sebagai data primer. Data yang ada di dalam teks dapat dianalisis melalui kata, frasa, kalimat, atau paragraf yang dapat memberikan informasi mengenai penggambaran bentuk keluarga matrilineal Minangkabau. Pengumpulan data dilakukan dengan metode pustaka melalui bentuk teknik baca-catat. Kemudian dibuat klasifikasi berdasarkan karakteristik data yang dibutuhkan. Oleh karena itu, selain metode analisis data maka harus dilakukan juga interpretasi terhadap data berupa kutipan dan potongan dialog yang terdapat pada teks. Setelah 
melakukan pembacaan mendalam, diskusi mengenai permasalahan yang dibahas di dalam novel akan dianalisis melalui teknik perbandingan dan dibantu menggunakan analisis elemen struktur naratif, seperti tokoh dan penokohan, alur, latar, sudut pandang, dan konflik dalam cerita. Analisis tersebut penting untuk mengetahui secara menyeluruh informasi terkait potret keluarga matrilineal di Minangkabau melalui interaksi yang dilakukan oleh para tokoh yang satu dengan yang lain.

\section{HASIL DAN BAHASAN}

Dalam masyarakat Minangkabau, peranan utama dari seorang laki-laki adalah sebagai mamak, bukan sebagai seorang suami atau ayah. Di dalam kedua novel ini, kedua pengarang menghadirkan tokoh mamak. Namun, kehadiran tokoh mamak di dalam kedua novel ditampilkan secara berbeda. Maka setelah melakukan pembacaan terhadap kedua objek penelitian ini, maka ditemukan potret keluarga matrilineal di Minangkabau yang ditampilkan dalam kedua novel.

\section{Potret Keluarga Matriarkal- Matrilineal Minangkabau}

Aku Tidak Membeli Cintamu merupakan novel yang berkisah tentang tokoh Suci Intan Baiduri, yang kerap dipanggil dengan sebutan Suci atau $\mathrm{Ci}$ di dalam cerita. Suci digambarkan sebagai seorang anak yang berasal dari daerah Pariaman yang merantau ke Jakarta. Ia memiliki satu orang saudara laki-laki dan satu orang saudara perempuan. Selain memiliki dua saudara, Suci digambarkan memiliki dua mamak rumah. Kedua mamak rumah ini merupakan adik laki-laki Bundo Suci. Di dalam cerita, keluarga Suci ditampilkan sebagai keluarga yang sangat kental menjunjung adat dan tradisi Minangkabau, khususnya adat dan tradisi di Pariaman berupa tradisi uang jemputan. Di dalam cerita Suci dan saudara lakilakinya digambarkan sebagai penentang tradisi uang jemputan yang diberlakukan oleh Bundonya, sedangkan saudara perempuannya sangat patuh dan tunduk pada adat dan tradisi yang diberlakukan oleh Bundonya. Saudara perempuannya menerima jodoh yang dipilihkan oleh Bundonya dan menggunakan tradisi uang jemputan untuk menjemput mempelai calon suami saudara perempuannya tersebut. Pantang bagi Bundo Suci menikahkan ketiga anaknya tanpa menggunakan tradisi uang jemputan karena dapat merendahkan martabat keluarga dan melanggar adat yang sudah berlaku.

Konflik dalam novel Aku Tidak Membeli Cintamu dimulai ketika Suci menentang untuk dijodohkan dengan lakilaki pilihan Bundonya yang berasal dari Pariaman. Alasan Suci menolak perjodohan itu karena ia tidak ingin menggunakan tradisi uang jemputan untuk menjemput laki-laki yang ingin dinikahkan dengannya. Menurutnya tradisi uang jemputan yang diberlakukan oleh Bundonya tidak sesuai lagi dengan adat nan sabana adat (adat yang sebanar-benar adat) di Minangkabau. Berbagai cara Suci menghindari perjodohan dengan laki-laki pilihan terakahir Bundo, salah satunya dengan cara menyibukkan diri di tempat kerjanya. Namun pada akhirnya tokoh Suci digambarkan dalam cerita bersedia menerima jodoh yang dipilihkan Bundonya , akan tetapi ia melakukan negosiasi kepada calon suaminya untuk tidak menggunakan tradisi uang jemputan dalam pernikahannya tanpa sepengetahuan Bundonya.

Pada Novel Aku Tidak Membeli Cintamu karya Desni Intan Suri ditemukan potret keluarga matrilineal Minangkabau digambarkan dengan keluarga yang menganut sistem matriarkal-matrilineal, maksudnya adalah selain garis kekerabatan keluarga ditarik menurut garis perempuan atau nenek moyang Ibu, kekuasaan di dalam potret keluarga ini juga berada di tangan ibu bukan mamak di dalam keluarga. Hal ini terlihat dari kutipan berikut ini.

[...] Alasan Kedua, ia tidak ingin terlibat banyak dalam istiadat yang 
seolah egois mementingkan diri sendiri. Sudah terlalu banyak ia melihat dalam keluarganya sendiri, yang menurutnya, menggunakan adat untuk kepentingan diri sendiri dan kekuasaan mutlak dari seorang ibu (Suri, 2012: 12).

Kutipan ini menunjukkan bahwa kekuasaan tertinggi dan tidak dapat dibantah dalam keluarga tokoh utama, yaitu Suci, berada di tangan Bundonya (salah satu panggilan untuk orang tua di Minangkabau). Hal ini sebagaimana yang diargumenatsikan oleh Asri (2013:70) dalam tulisannya bahwa budaya Minangkabau menganut sistem matriarkal yang menempatkan posisi perempuan sebagai figur sentral dalam keluarga (yang dilambangkan dengan predikat Bundo Kanduang). Segala persoalan dalam keluarga selalu dinisbatkan kepadanya dan dia adalah penentu kebijaksanaan keluarga, sedangkan posisi laki-laki dalam keluarga hanya berfungsi sebagai periferal. Mamak (paman) hanya bertugas sebagai pelindung keluarga, termasuk dalam harta warisan keluarga. Selain itu, mamak dalam budaya Minangkabau hanya berfungsi sebagai protektoral dan seremonial untuk berhadapan dengan dunia luar. Apa yang disampaikan oleh mamak kepada dunia luar adalah suara keluarga yang sebelumnya telah disepakati dan diputuskan oleh Bundo Kanduang. Dari pemaparan tersebut terlihat bahwa dengan adanya sistem matriarkal itu, budaya Minangkabau memberikan ruang dan kesempatan kepada perempuan untuk memiliki, sebagaimana yang diargumentasikan oleh Asri (2013:70).

Tokoh mamak di dalam novel ini digambarkan sebagai pemimpin untuk kemenakan dan pelindung di dalam rumah yang patuh kepada Bundo Suci. Hal ini dapat dilihat dalam kutipan berikut ini.

Dua pamannya, Pak Aciak Munir dan pak aciak Sabri, merupakan dua adik lelaki yang selalu setia dibelakang kakak perempuan mereka, Rosna Juwita. Apa pun keputusan kakak perempuan mereka, akan mereka setujui dengan sepenuh hati. (Suri, 2012: 86)

Walaupun tokoh mamak tidak menampilkan sosok pelindung dan pemimpin untuk kemenakan dalam keluarga Suci, mamak rumah di dalam keluarga Suci tetap bertanggung jawab dalam mencarikan kemenakannya jodoh. Di Minangkabau semua saudara laki-laki dari ibu disebut mamak rumah, saudara ibu yang tertua disebut tungganai. Tiap-tiap rumah dikepalai oleh mamak rumah yang paling tua, bukan dikepalai oleh suami. Salah satu tugas mamak rumah adalah mencarikan calon suami untuk kemenakan perempuannya. Akan tetapi, kedua tokoh mamak rumah Suci ditampilkan sebagai mamak rumah yang mencarikan jodoh untuk kemenakannya hanya untuk mendapatkan keuntungan untuk pribadinya sendiri dari tradisi uang jemputan yang akan diberikan kepada calon suami untuk kemenakannya.

Tapi dua pamanya ini memang sudah mutlak menjadi kaki tangan Bundonya. Khusus memburu jodoh untuk dirinya, kedua pamannya ini ambil andil besar dan bertindak sangat menguasai. Untuk persoalan menjodohkan kemenakan, mereka berdua selalu menggunakan pepatah anak dipangku kamanakan dibimbiang untuk memperlakukan adat jual beli perjodohan anak dan kemenakanya. Apalagi maksudnya kalau tidak untuk mengeruk keuntungan dari uang jemputan yang ditetapkan. (Suri, 2012: 8889)

Selain itu, mamak rumah tidak lagi menampilkan sosok pelindung dan pemimpin untuk kemenakannya di dalam keluarga matrilineal Minangkabau, yaitu sebagai seorang pemimpin yang dihargai dan didengar pendapatnya di dalam keluarga. Namun dalam paragraf ini 
ditemukan bahwa pendapat saudara dari pihak suamilah (ayah) yang didengar dan dihargai di dalam keluarga Bundo. Hal ini dapat dilihat pada kutipan berikut ini.

Untunglah tante Riska ikut campur. Semuanya menyegani Tante Riska. Walau tante Riska datang dari pihak keluarga Ayahnya,... Apalagi sekarang Tante Riska duduk di DPR dan menggepalai sebuah lembaga saintis Jakarta. Semuanya tidak berkutik bila Tante Riska bicara. (Suri, 2012:89)

Kutipan tersebut menunjukkan bahwa di dalam keluarga Suci pasumandan sangat dihargai keberadaannya dan didengar suaranya oleh keluarga Suci dibandingkan dengan mamak rumah. Mamak rumah di dalam cerita digambarkan tidak memiliki wibawa dan sifat kepemimpinan seorang "mamak" di Minangkabau. Di Minangkabau setiap kelompok atau kaum mulai dari jurai (kelompok yang paling kecil) sampai sasuku (kelompok yang paling besar) harus memiliki seorang pemimpin, yakni seorang mamak karena mamaklah memiliki kekuasaan terhadap anggota-anggota kelompok dan kekuasaan mewakili kelompok atau anggota-anggota kelompok di dalam hubungan antar kelompok.

Sedangkan pasumandan yang di dalam cerita ditampilkan melalui sosok Tante Riska. Pasumandan merupakan sebutan untuk saudara perempuan yang berada dalam kaum suami dari pihak istri. Misalnya, suami dari rumah gadang A yang kawin dengan isteri dari rumah gadang $\mathrm{B}$, maka pasumandan bagi isteri adalah perempuan yang berada dalam kaum suami. Saya berargumentasi bahwa keberadaan Tante Riska yang disegani dalam keluarga Bundo Suci karena status sosialnya (pekerjaan) dan memiliki pendidikan yang lebih tinggi di bandingkan mamak rumah Suci yang digambarkan sebagai penjaga toko emas milik Bundo Suci. Akibatnya pasumandan yang bukan satu kekerabatan dari pihak Bundo Suci menggeser "suara" mamak rumah yang semestinya harus lebih didengarkan karena ia seorang pemimpin kelompok di dalam keluarga Bundo Suci. Hal ini memperlihatkan bahwa peran mamak sebagai pemimpin di dalam keluarga mulai pudar.

Kedudukan suami atau sumando (sebutan untuk suami dari pihak keluarga istri) dalam keluarga perempuan istrinya adalah urang asiang (orang asing atau luar) dalam kelompok istrinya. Hal ini ditunjukkan dalam pepatah bak abu di ateh tunggua (seperti abu di atas tunggul). Pepatah ini menunjukkan bahwa posisi seorang suami sangat bergantung sejauh mana "kebaikan hati" keluarga istri untuk tetap mempertahankan dirinya, seperti abu di atas tanggul yang siap diterbangkan apabila angin kencang datang. Hal ini dapat dilihat pada kutipan berikut ini.

Suci masih ingat betapa kejam Bundonya merendahkan suaminya sendiri dengan sistem uang jemputan itu. Sementara ayahnya terlihat diam saja. Tak berkutik dengan perkataan istrinya. Persis seperti kerbau yang sudah dicucuk hidungnya. (Suri, 2012:70).

Kutipan tersebut menggambarkan bahwa tokoh ayah di dalam keluarga tidak dihargai sebagai seorang suami oleh Bundonya. Sikap Bundo Suci tidak menghargai karena ayah Suci dulunya dijemput oleh Bundonya sewaktu akan menikah dengan uang jemputan. Uang jemputan merupakan tradisi perkawinan Minangkabau yang khusus di daerah Pariaman. Moeleca (2015: 2) menyebutkan bajapuik atau japuiktan dipandang sebagai kewajiban pihak keluarga perempuan yang membayar calon suaminya dengan jumlah disesuaikan dengan status sosial yang disandang. Uang yang dibayarkan kepada pihak calon suami dinamakan uang japuik, kesepakatan transaksi ini dilakukan sebelum hari akad pernikahan dilakukan. Sehingga dalam hal ini, tradisi perkawinan Minangkabau pada proses peminangnya di prakarsai oleh pihak perempuan, sebagaimana diargumentasikan oleh 
Moeleca (2015). Di dalam cerita tokoh ayah digambarkan dijemput dengan uang jemputan yang sangat besar, yaitu sebuah toko emas. Hal ini dapat dilihat dalam kutipan berikut ini.

"Ayahmu tu dulu dijemput dengan sebuah kedai emas dari Uwo kalian, tahu tidak?! Lihatlah sekarang Ayahmu itu, nyaman hidupnya dengan kedai emas itu!" (Suri, 2012:70)

Jika suara suami atau ayah Suci tidak didengar dan disegani oleh Bundo Suci. Berbeda halnya dengan saudara ayah Suci yang bernama Tante Riska yang lebih disegani oleh Bundo Suci. Hal ini dapat dilihat di dalam kutipan berikut ini.

"Mau zaman modern atau Siti Nurbaya sama sajalah. Yang namanya perempuan akhrinya bakal jadi istri orang.... Cari saja suami yang betul dan menjamin kehidupan masa depan kita. Habis tu punya anak, nah didiklah anak $t u$ baik-baik. Itu sajalah kehidupan perempuan $n i$ dari zaman ke zaman!" begitu ucapan istrinya saat Suci mengajukan permintaan untuk melanjutkan sekolah ke universitas di Jakarta. Untung ada Riska, kakak perempuannya. Istrinya sangat segan dengan Riska karena ia seorang saintis yang sering muncul menjadi komentator pendidikan di televisi. (p4:hal 7879)

Seperti yang telah dipaparkan sebelumnya keberadaan Tante Riska yang bukan satu garis keturunan dengan pihak keluarga Bundo Suci lebih didengar dan disegani oleh Bundo. Hal ini terutama tingkat pendidikan dan status sosial yang tinggi dibandingkan ayah Suci yang hanya sebagai "suami" Bundo saja, sedangkan Tante Riska di dalam kutipan disebutkan bahwa ia adalah seorang saintis.

Beckmann (2000:97) memaparkan bahwa menurut adat, hanya sedikit kekuasaan yang berada di dalam peranan bapak. Mamaklah yang menjadi pusat kekuasaan, dialah yang mengambil tindakan disiplin terhadap kemenakan, jika hal itu dianggap perlu. Serta mamaklah yang menjadi wakil kemenakannya dalam urusan-urusan sosial dan politik, serta urusan-urusan terkait pusako anak-anak juga tunduk pada kekuasaan mamak. Sebagai bapak, lelaki Minangkabau diharuskan "memangku anak-anaknya", sedangkan sebagai mamak mereka harus "membimbing kemenakannya". Hal ini dapat dilihat pada kutipan berikut ini.

Di mana si kepala keluarga? Pak Syahbuddin tetap menempatkan dirinya sebagai outsider.

Tampaknya ia memegang teguh strukutr adat Minang, yang mana kedudukan suami sebagai orang datang atau urang sumando merupakan kedudukan yang lemah untuk dibawa dalam musyawarah keluarga pihak istrinya, walau yang diperbicangkan adalah anak kandung sendiri (Suri, 2012:136).

Kutipan tersebut menegaskan bahwa Pak Syahbuddin yang digambarkan sebagai ayah Suci tidak dapat berbuat apa-apa, walaupun terkait permasalahan anaknya sendiri. Suami ditampilkan sebagai "orang luar" yang tidak boleh mencampuri urusan keluarganya sendiri, karena dalam sistem keturunan matrilineal, ayah bukanlah anggota dari keturunan anak-anaknya. Dia dipandang tamu dan diperlakukan sebagai tamu dalam keluarga, yang tujuannya terutama untuk memberi keturunan, sebagaimana yang diargumentasikan oleh Naim (1979: 18). Lebih lanjut Naim (1979) menerangkan bahwa tempat yang sah bagi suami adalah dalam garis keturunan ibunya di mana dia berfungsi sebagai anggota keluarga laki-laki dalam garis keturunan itu. Secara tradisi, dia adalah wali dari keluarga ibunya, pelindung atas harta benda keluarga ibunya, dan sebagai mamak untuk kemenakannya. 
Kutipan berikut ini akan menunjukkan bahwa ayah sebagai kepala keluarga di Minangkabau tidak menampilkan sebagai seorang kepala keluarga untuk istri dan anak-anaknya.

Ia menoleh pada ayahnya. Ia berharap ayahnya akan membantunya mengantasi kesulitannya ini. Namun lagi-lagi dilihat ayahnya hanya menganggukangguk sambil matanya tetap memandang istrinya. Sesekali ia menoleh pada Suci dengan wajah tanpa makna. Terlihat sekali bahwa ia benar-benar berpijak pada keputusan istrinya. Suci merasa muak melihat sikap ayahnya (Suri, 2012: 76-77).

Secara tidak langsung kutipan tersebut menunjukkan bahwa ibu ditampilkan sebagai pemimpin keluarga dan kekuasaan tertinggi berada di tanganya, sedangkan tokoh ayah ditampilkan sebagai pemimpin keluarga yang tidak bisa berbuat apa-apa ketika terjadi perdebatan antara Suci dan Bundo berdebat. Tokoh ayah digambarkan dalam cerita ini sebagai ayah yang tidak dapat ikut campur urusan keluarganya sendiri dan ia hanya dapat mengikuti apapun keputusan istrinya. Hal ini dibuktikan dengan sikap ayah Suci yang ditampilkan hanya sebagai seorang pengamat dalam perdebatan anatara istri dan anaknya. Ia hanya melihat Suci dengan wajah tanpa makna dan menganggukangguk sembil memandang istrinya, hal ini seperti yang telah dipaparkan dalam kutipan Suri (2012:76-77)

Walaupun di dalam cerita sosok ayah ditampilkan sebagai sosok yang tidak memiliki kekuasaan di dalam keluarganya dan tunduk atas segala keputusan istrinya dalam urusan keluarga. Di dalam cerita ditampilkan suatu peristiwa ketika tokoh ayah mencoba untuk menyampaikan pendapatnya untuk mencarikan jalan keluar terkait perdebatan yang terjadi antara Bundo dan Suci walaupun hal tersebut membuat ayah Suci terbata-bata menyampaikan pendapatnya.
"Ngg... hmm Ros... kupikir tak apalah Suci datang malam acara itu saja. Orang kerja kan ndak bisa sembarangan libur..," katanya terbata-bata, mencoba mencari jalan tengah. Suci mendadak mengangkat kepalanya, memandang ayahnya.... Kadang kala ia iba melihat ayahnya. Sikap yang seharusnya tampil sebagai penentu atau decision maker keluarga sudah diambil alih oleh istrinya. (Suri, 2012:79)

Potret ayah di dalam keluarga yang ditampilkan di dalam novel Aku Tidak Membeli Cintamu karya Desni Intan Suri menunjukkan bahwa perkawinan di Minangkabau tidak menciptakan keluarga inti (nuclear family) yang baru, karena suami atau istri masing-masing tetap menjadi anggota dari garis keturunan mereka masing-masing. Oleh sebab itu, sebagaimana yang diargumentasikan oleh Naim (1979: 21) pengertian tentang keluarga inti yang terdiri dari ibu, ayah, dan anak-anak sebagai suatu unit tersendiri tidak terdapat dalam strukutur sosial Minangkabau oleh karena dia selalu ternaung oleh sistem garis keturunan ibu yang lebih kuat. Sehingga, anak-anak dihitung sebagai anggota garis keturunan ibu dan selalu lebih banyak melekatkan diri kepada sang ibu serta anggota-anggota lainnya dalam garis keturunan itu.

\section{Potret Keluarga Patriarkal- Matrilineal Minangkabau}

Potret keluarga matrilineal Minangkabau berbentuk patriarkalmatrilineal ditampilkan di dalam novel Negeri Perempuan karya Wisran Hadi. Novel ini berkisah kehidupan keluarga Reno yang digambarkan sebagai anak Bundo yang akan menjadi pewaris kerajaan keluarga Bundo. Keluarga Bundo digambarkan tinggal di Puri Alam, yang letaknya berada di Nagariko. Keluarga Reno ditampilkan sebagai keluarga pewaris kerajaan di Nagariko dan ia memiliki seorang Engku (mamak atau 
saudara laki-laki Bundo), ayah, Oncu (adik perempuan satu ibu dengan Bundo), serta saudara laki-laki dan sepupu laki-laki dari Oncu. Setelah melakukan pembacaan mendalam terhadap novel Negeri Perempuan ditemukan adanya konflik perebutan kekuasaan antara pihak keluarga Reno dengan pihak yang "terpaksa diakui" sebagai bagian keluarga besar Reno, yaitu Pak Barajoan (memiliki jabatan sebagai kepala daerah) dan Diringgiti (orang kaya yang "diangkat" sebagai menantu oleh Bundo) untuk mendirikan Rumah Gadang Sembilan Ruang milik keluarga Reno. Kedua laki-laki ini digambarkan sebagai pihak yang "terpaksa diakui" yang bersikap semena-mena dan mengabaikan norma adat yang berlaku karena telah memiliki gelar adat, yaitu sebagai penghulu. Karena jabatannya sebagai penghulu, sekaligus memiliki jabatan sosial yang tinggi di dalam masyarakat Minangkabau (Barajoan sebagai kepala daerah dan Diringgiti pengusaha kaya), mereka ingin menguasai harta pusako dan menguasai hak untuk mendirikan Rumah Gadang Sembilan Ruang yang akan didirikan oleh keluarga Reno sebagai pengganti Rumah Gadang yang dulu terbakar.

Pada novel Negeri Perempuan karya Wisran Hadi ditemukan bentuk keluarga yang masih dipimpin oleh mamak (yang mana di dalam cerita mamak dipanggil engku), sedangkan untuk peranan laki-laki (mamak) dan ibu ditampilkan sama-sama memiliki peranan yang tidak saling mendominasi di dalam keluarga, akan tetapi saling melengkapi. Ibu di dalam cerita dipanggil dengan Bundo memiliki peranan di dalam rumah, sedangkan mamak bertindak sebagai pelindung dan perwakilan keluarga jika berhadapan dengan dunia luar. Tidak hanya garis keturunan yang ditarik dari pihak perempuan atau ibu, hak milik atas harta pusaka (seperti rumah dan tanah) menjadi hak milik atau diberikan kepada perempuan. Selain itu, yang menjadi puncak di dalam rumah ialah nenek yang perempuan (Hamka, 1963). Di sisi lain,
Hamka juga mengungkapkan bahwa di Minangkabau adanya posisi yang sama antara laki-laki dengan perempuan, tidak ada yang saling menonjol. Hal ini sebagaimana yang dipaparkan oleh Hamka dalam bukunya, yaitu

"Rumah tangga tidak ada di Minangkabau. Sebab kuasa orang laki-laki tidak ada sama sekali. Orang laki-laki hanja "Rantjak dilabuah", elok keluar, padahal didalam hantjur lebur. Biar dia seorang ninik mamak jang memegang 'adat lembaga, bergelar Datuk Menggonjang' Alam, kuasanja kepada anaknja sendiri tidak ada! Dan djngan disangka pula kekuasaannja penuh dirumah kemenakannja dan persukuannja. Kuasanja hanja diluar, bukan di dalam" (Hamka, 1963:50).

Dari argumentasi yang dipaparkan oleh Hamka bahwa kekuasaan laki-laki berada di luar, sedangkan perempuan di dalam rumah. Hal ini memperlihatkan bentuk budaya yang egaliter. Navis (1999:60) memaparkan bahwa egaliter menurut alam pikiran Minangkabau berarti persamaan atau kesetaraan yang menunjukkan bahwa laki-laki maupun perempuan memiliki kedudukan yang sama, hal ini sesuai dengan pepatah Minangkabau duduak samo randah, tagak samo tinggi (duduk sama rendah, ketika berdiri sama tinggi).

Kutipan berikut ini menunjukkan bahwa mamak memiliki peranan sebagai pemimpin dan perwakilan keluarga jika berhadapan dengan dunia luar.

Dalam tatacara keluarga Bundo, anggota keluarga yang paling tualah yang semestinya menempati tempat duduk pucuk adat atau duduk pada tempat kedudukan raja.

Anggota keluarga yang tertua adalah Bundo, tapi karena dia seorang perempuan kedudukan itu diserahkan pada Engku, saudara laki-lakinya (Hadi, 2011: 5). 
Kutipan tersebut menunjukkan bahwa kepemimpinan seorang mamak dalam kelompok keluarga matrilineal masih dijalankan oleh mamak di dalam keluarga. Selain itu, mamak dalam potret keluarga matrilineal bentuk patriarkal-matrilineal ini masih ditampilkan sebagai pengambil keputusan di dalam keluarganya ketika ada persoalan terkait keluarganya. Hal ini dapat dilihat dalam kutipan berikut ini.

Simarajo membicarakan hal itu dengan Reno. Reno lebih mudah dan lebih leluasa diajak bicara dibanding dengan Engku. Jika Reno setuju, tentu Engku akan mau mempertimbangkan

kembali apa yang diputuskan (Hadi, 2001: 247).

Kutipan tersebut menunjukkan bahwa sepanjang menyangkut urusan-urusan intrakelompok, mamak (pada tingkat kelompok apa saja) bertanggung jawab memelihara tata tertib di dalam kelompok dan untuk urusan di luar, mamak bertanggung jawab untuk setiap tindak pelanggaran adat yang mungkin dilakukan oleh anggota kelompok, sebagaimana yang diargumentasikan oleh Beckmann (2000). Tingkat kelompok yang dipaparkan oleh Beckmann (2000) adalah sebuah kelompok keturunan mulai dari kelompok berdasarkan keturunan, yaitu sa-jurai, sabuah gadang, sa-paruik, dan sa-suku. Dalam cerita mamak Reno (yang biasa disebut engku) ditampilkan sebagai seorang yang "setengah-setengah" menjalankan perannya sebagai mamak atau pemimpin untuk kaumnya, hal ini dapat dilihat melalui kutipan berikut ini.

".Akan tetapi engku menolak pula untuk duduk sebagai pucuk adat atau raja dalam acara peresmian. Engku menganggap acara seperti itu tak ubahnya sebuah sandiwara yang mengambil latar belakang sejarah" (Hadi, 2001: 5).

Di Minangkabau mamak memiliki peran sebagai wakil dari kelompok (keluarga) dalam berhubungan dengan kelompok lain. Menurut Beckmann (2000:95) mamak sebagai wakil dalam kelompok berlaku dalam semua jenis hubungan, salah satunya hubungan sosial politik, seperti mewakili kelompok di dalam nagari. Namun pada kutipan tersebut mamak digambarkan sebagai sosok yang menolak untuk mewakili kelompoknya dalam sebuah acara. Di dalam cerita mamak menunjuk kemenakannya untuk mewakili kelompok dalam acara peresmian tersebut. Hal ini dapat terlihat dalam kutipan berikut ini.

"Untuk memenuhi ketentuan siapa yang harus duduk sebagai pucuk adat atau raja, Engku menunjuk Muning yang baru sebulan diwisuda di Fakultas Hukum" (Hadi, 2001: 5).

Di dalam keluarga hubungan ibu dan ayah ditampilkan dalam novel Negeri Perempuan sangat berbeda dari potret keluarga yang ditampilkan di dalam novel Aku Tidak Membeli Cintamu. Ibu ditampilkan sebagai sosok yang sangat menghormati suaminya. Hal ini dapat dilihat dalam kutipan berikut ini, "Anakanak Ayah tidak ada lagi yang di rumah. Sedangkan anak-anakku selalu bertambah," kata Bundo lembut meredakan kemerahan suaminya" (Hadi, 2001: 17).

Sosok ayah juga ditampilkan di dalam cerita sebagai sosok yang dekat dengan anaknya. Hal ini terlihat ketika tokoh ayah ikut menasehati Reno dikala Reno ada masalah.

"Kita baru dikatakan hidup apabila ada keinginan untuk menjawab setiap persoalan yang ada. Jika tidak mau atau menghindar daripadanya, sama halnya dengan mati. Yang tidak punya persoalan dan tidak dipersoalkan hanyalah orang mati," kata Ayah membangkitkan semangat Reno bila dia merasa terpuruk dalam kubangan perosalan- persoalan (Hadi, 2001: 271). 
Selain itu, sosok ayah digambarkan memiliki kedekatan dengan anggota keluarga Bundo lainnya. Ketika terjadi permasalahan dalam keluarga Bundo tokoh ayah ditampilkan sebagai sosok yang suaranya didengar dalam keluarga Bundo, hal ini terlihat ketika ayah Reno pernah memberikan nasihat kepada engku ketika ada masalah terkait silsilah keluarga Reno yang salah dipajang di Puri Alam. Hal ini ditunjukkan dalam kutipan berikut ini.

Engku tetap bertahan agar membiarkan saja silsilah yang salah dipajang di Puri Alam.

Sementara Reno tetap mendesak agar diizinkan menyalin kembali silsilah yang ada. Reno dengan berbagai alasan berusaha meyakinkan Engku begitupun para penghulu. Engku tetap bertahan. Sampai akhirnya Ayah ikut campur dalam persoalan ini. (Hadi, 2001:30)

Lebih lanjut nasihat yang diberikan ayah kepada mamak terhadap permasalahan keluarga Bundo diterima oleh engku sebagai pemimpin dan pelindung keluarga Bundo. Hal ini terlihat dari kutipan berikut ini.

"Apa kita berdosa kalu silsilah yang asli disalin kembali?" tanya Ayah. Engku menggeleng."Apa kekeramatan silsilah itu akan hilang kalau disalin ulang?" tanya Ayah lagi. Engku menggeleng lagi. "Kalau tidak, apa salahnya disalin. Itu kan bahagian dari ilmu pengetahuan," lanjut Ayah. Akhirnya Engku mengizinkan menyalin silsilah mereka. (Hadi, 2001:30)

Kutipan tersebut menunjukkan bahwa urang sumando yang ditujukan kepada ayah Reno tidak dianggap sebagai tamu dan diperlakukan sebagai tamu di dalam keluarga Bundo. Ayah ditampilkan sebagai sosok yang dihargai dan didengar nasehatnasehatnya ketika ada permasalahan dan perdebatan di dalam keluarga Bundo.
Dalam masyarakat Minangkabau, menurut Beckmann (2000:97) peranan laki-laki sebagai urang sumando, mereka ikut dalam pengambilan keputusan yang berpengaruh terhadap urusan harta benda anak-anak mereka, dan di dalam upacaraupacara yang menandai masa akil balig anak-anak tersebut. Selain itu, para bapak dapat melakukan pengawasan tertentu terhadap keuangan istri dan anak-anaknya dengan cara mengalihkan perolehan pendapatan mereka sendiri. Lebih lanjut Beckmann (2000:98) menambahkan bahwa secara konseptualisasi adat mengenai peranan bapak telah mengalami modifikasi melalui wawasan Islam mengenai kedudukan Bapak. Dalam urusan-urusan keagamaan, bapak biasanya mewakili anak-anaknya. Secara khusus, bapak bertindak sebagai wali "menurut agama" (wali syarak), di samping mamak yang bertindak sebagai wali "menurut adat (wali adat).

Selain mamak yang memiliki kedudukan dan peranan penting dalam keluarga matrilineal, perempuan di Minangkabau juga memiliki kedudukan dan peranan penting. Salah satunya sebagai unduang-unduang ka Madinah, payuang panji ka dalam sarugo, maksudnya adalah penjadi pelindung, pemberi arah dan contoh teladan dalam budi pekerti yang sesuai dengan sunnah rasulullah, penentu apakah kaum itu akan menjadi orang-orang saleh, beriman atau sebaliknya. Hal ini dapat terlihat ketika Bundo Reno menasehati engku ketika kaum engku di hina oleh Barajoan.

"Dari dulu aku melarangmu bekerja. Dari hasil tanah pusaka ini, kita akan hidup tanpa minta-minta! Salahmu sendiri. Kau ingin jadi pegawai! Kau ingin jadi pejabat! Selagi kau masih menjadi bawahan, kau akan mendapat tekanan! Berhentilah bekerja. Minta pensiun muda," Bundo menangis sambil meremas punggung Engku. (Hadi, 200:143) 
Tidak hanya menjadi sosok pemberi arah untuk anggota keluarganya, Bundo juga menjadi sosok yang memberikan contoh teladan untuk anaknya Reno. Hal ini dapat terlihat dalam kutipan berikut ini.

"Apa yang kau inginkan itu adalah keinginanku juga sejak dulu, Reno. Aku ingin tata cara dan adat kita sampai kapan pun harus dipertahankan. Tapi dalam hidup ini ada hal-hal yang berada di luar jangkauan. Bukan berarti kita mengalah, tetapi mundur selangkah untuk dapat menentukan arah. Mungkin hati ini teriris-iris menyaksikan acara tadi sore, tapi jangan rasakan sakitnya. Kau harus merasakan sesuatu yang jauh dan dalam dari kesakitan itu. Mungkin dari semuanya itu menjadikan kau perempuan yang tegar untuk masa yang akan datang. Anggap kesalahan yang kita lakukan hari ini sebagai cambuk yang dapat mendera diri kita agar terus mempertahankan pusaka dan adat negeri ini," kata Bundo sendu membarut kepala Reno yang diletakkan di pangkuannya. (p1: hal 92-93).

\section{PENUTUP}

Dalam penelitian ini, saya menemukan dua potret bentuk keluarga matrilineal di Minangkabau, yaitu bentuk keluarga matriarkal-matrilineal dan patriarkal-matrilineal. Potret keluarga matrilineal Minangkabau berbentuk matriarkal-matrilineal ditampilkan di dalam novel Aku Tidak Membeli Cintamu karya Desni Intan Suri. Kekuasaan di dalam keluarga berada di pihak ibu, sedangkan mamak ditampilkan sebagai sosok yang menjadi perpanjangan tangan ibu di dalam keluarga, bukan sebagai pemimpin untuk kemenakannya dan pelindung keluarganya. Posisi mamak dan ibu pada bentuk keluarga ini sangat timpang karena segala keputusan berada di tangan ibu, sedangkan mamak dan ayah mengikuti segala keputusan yang ditetapkan ibu untuk anak-anaknya. Untuk posisi dan peranan ayah dalam potret keluarga bentuk matriarkal-matrilineal ditampilkan sebagai suami yang patuh kepada istrinya dan tidak bisa ikut campur dalam mengurusi permasalahan terkait anak-anaknya. Ia hanya mengikuti segala keputusan istrinya saja.

Kemudian, potret keluarga matrilineal Minangkabau berbentuk patriarkal-matrilenal ditampilkan dalam novel Negeri Perempuan karya Wisran Hadi. Bentuk keluarga patriarkalmatrilenal, maksudnya adalah di dalam keluarga mamak bertindak sebagai pemimpin untuk kemenakannya dan pelindung untuk keluarganya (kaumnya). Potret keluarga patriarkal-matrilineal yang saya temukan di dalam novel tidak serta merta menjadikan mamak memiliki posisi yang lebih tinggi dan peranan yang lebih penting di dalam keluarga, begitu pula kekuasaannya pun tidak mutlak atau penuh di tangannya, melainkan posisi dan perananya kedudukanya sama dengan ibu (atau disebut dengan Bundo Kanduang) di dalam kaum. Mamak berperan sebagai pemimpin untuk kemenakannya dan pelindung untuk keluarga kaumnya (keluarga satu garis keturunan ibu), sedangkan ibu atau yang disebut Bundo kanduang berperan menjaga harta pusaka dan nama baik keluarga. Dalam pengambilan keputusan tidak mutlak berada di pihak mamak, melainkan ada beberapa hal sebuah keputusan diambil melalui proses musyawarah terlebih dahulu. Anggota musyawarah ini hanya diikuti pihak keluarga, kemudian dari hasil musyawarah barulah mamak mengambil keputusan. Untuk peranan dan posisi ayah di dalam keluarganya sendiri ditampilkan sebagai sosok yang memiliki kedekatan dengan keluarga istrinya. Dia juga ditampilkan sebagai sosok yang bijaksana untuk keluarganya sendiri.

\section{DAFTAR SUMBER}

\section{Jurnal, Tesis, dan Makalah}

Andriani, Yelmi. 2011. Perubahan Sosial dalam Novel Negeri Perempuan Karya Wisran Hadi Suatu Tinjauan Sosiologi Sastra. Skripsi. Padang: Universitas Andalas. 
Asri, Yasnur. Refleksi Ideologi Wanita Minangkabau Dalam Novel Negeri Perempuan Karya Wisran Hadi. Jurnal Humaniora Vol 25, No 1 Hal 69-81, Februari 2013.

Friade, Fauzi. 2016. Aku Tidak Membeli Cintamu dengan judul Pemaknaan Novel "Aku Tidak Membeli Cintamu" Karya Desni Intan Suri (Tinjauan Semiotik). Skripsi. Padang: Universitas Andalas.

Lidya Nadianti. 2018. Persepsi Yang Keliru Terhadap Adat Kawin Bajapuk Dalam Novel Aku Tidak Membeli Cintamu Karya Desni Intan Suri Tinjauan Sosiologi Sastra. Skripsi. Padang: Universitas Andalas.

Moeleca, Bunga. Konstruksi Realitas Makna "Bajapuik" Pada Pernikahan Bagi Perempuan Pariaman Di Kecamatan Pasir Penyu. Jom FISIP Vol2, No $1 \mathrm{Hal}$ 1-14, Februari 2015.

Novianti, Hasmi. Problematika Kebudayaan Dalam Novel Aku Tidak Membeli Cintamu Karya Desni Intan Suri. Deiksis: Jurnal Pendidikan Bahasa dan Sastra Indonesia. Vol 5, no 1 tahun 2018. Hal 80-90.

Pelita, Indah. 2017. Citra Perempuan Minangkabau dalam Novel Negeri Perempuan Karya Wisran hadi dan Novel Limpapeh Karya A.R Rizal: Kajian Intertekstual. Skripsi. Padang: Univeristas Negeri Bung Hatta.

Sani, Hidayati. 2017. Citra Perempuan Minangkabau dalam Novel Negeri Perempuan Karya Wisran Hadi (Analisis Kritik Sastra Feminis). Skripsi. Padang: Universitas Andalas.

Syafnita, Nelvia. 2014. Citra Perempuan Minangkabau Dalam Novel Aku Tidak Membeli Cintamu Karya Desni Intan Suri. Skripsi. Padang: Univeristas Negeri Padang.

\section{Buku}

Azwar, Welhenri. 2001.

Matrilokal Dan Status Perempuan Dalam Tradisi Bajapuik, Studi Kasus Tentang Perempuan Dalam Tradisi Bajapuik. Galang Press: Yogyakarta.
Benda-Beckmann, Franz von. 2000. Properti Dan Kesinambungan Sosial. Jakarta: Grasindo.

Damono, Sapardi Djoko. 2005.

Pegangan Penelitian Sastra Bandingan. Jakarta: Pusat Bahasa Departemen Pendidikan Nasional.

Hadi, Wisran. 2001.

Negeri Perempuan. Jakarta:Pustaka Firdaus.

Hamka. 1963. Adat Minangkabau Menghadapi Revolusi. Firma Tekad: Djakarta.

Moleong, J. Lexy. 2004. Metodologi Penelitian Kualitatif. Bandung: PT Remaja Rosdakarya Offset.

Naim, Mochtar. 1979. Merantau Pola Migrasi Suku Minangkabau. Yogyakarta:Gadjah Mada University Press.

Navis, A.A. 1999. Yang Berjalan Sepanjang Jalan, Kumpulan Karangan Pilihan. Jakarta: Grasindo.

Subadio, Ulfah Maria dan T.O Ihromi (ed). 1978.

Peranan dan Kedudukan Wanita Indonesia Bunga Rampai TulisanTulisan. Gadjah Mada University Press: Yogyakarta.

Suri, Desni Intan. 2012.

Aku Tidak Membeli Cintamu. Jakarta: Jendela.

\section{Website}

Ningsih, Kurnia. Perempuan Dan Modrenisasi Dalam Novel Negeri Perempuan. http://www.mantagibaru.com/2013/12/p erempuan-dan-modernisasi-dalamnovel.html Diakses pada tanggal 24 November 2018.

Rumiana. 2015. Sistem Nilai Budaya Minangkabau Dalam Novel Aku Tidak Membeli Cintamu Karya Desni Intan Suri. Artikel ilmiah. Padang: STKIP PGRI Sumatera Barat. Diunduh pada halaman

file://C:/Users/LENOVO/Downloads/Si stem\%20Nilai\%20Budaya\%20Minangk abau $\% 20$ dalam $\% 20$ Novel $\% 20$ Aku $\% 20$ 
Tidak\%20Membeli\%20Cintamu\%20Kar ya\%20Desni\%20Intan\%20Suri(1).pdf pada tanggal 29 Januaru 2019, pukul 15.06 .

Susanti, Desi. Kebudayaan Sosial Dalam Novel Aku Tidak Membeli Cintamu Karya Desni Intan Suri. Diunduh pada halaman https://anzdoc.com/queue/kebudayaansosial-dalam-novel-aku-tidak-membelicintamu-kary.html pada tanggal 29 Januari 2019, pukul 21.04.

Syahrizal dan Sri Meiyenti. 2012. Sistem Kekerabatan Minangkabau Kontemporer: Suatu Kajian Perubahan Dan Keberlangsungan Sistem Kekerabatan Matrilineal Minangkabau. Prosiding: International Conference on Indonesian Studies ISSN 2087-0019. Unity, Diversity and Future, Fakultas Ilmu Pengetahuan Budaya Universitas Indonesia. Bali, 9-10 Februari 2012. (dalam https://icssis.files.wordpress.com/2012/0 5/09102012-71.pdf). 
